\author{
Sylwia Różycka-Jaroś \\ Uniwersytet Warszawski \\ s.rozycka-jaros@uw.edu.pl
}

\title{
Historyczno-prawna analiza sytuacji dzieci w epoce Rousseau
}

\section{Summary \\ Historical and legal analysis of the situation of children in the age of Rousseau}

The aim of this article is to bring the reader closer, in a synthetic way, to the legal realities in which children had to work in the eighteenth century in Europe. The analysis applies in particular to the private law shaping the relationship between parents and children. The first issue taken into account was the varied situation of children of married and unmarried couples because of the fact that children born out of wedlock lived outside the family and had no personal rights and property such as were due to the child born in a marriage. A considerable part of the publication is devoted to the rights resulting from parental authority over a child, which directly shaped his position in the family and in society. The emphasis was put on a particularly strong position in order to stress the father as a head of the family. The rules prevailing at that time relating to the upbringing of children and their education were illustrated, taking into account the different situation of sons and daughters. Important issues were presented relating to the entering into marriage by adolescent children, and their financial situation. Also mentioned briefly were legal sanctions threatened for abuse by children of parents, as well as parents for abandoning or killing a child. In the final part of the article legal regulations of eighteenth-century Europe are quoted. The enforcement of these regulations foreshadowed a change in legal concepts of the child and the treatment of children within a legal system.

Słowa klucze: dziecko małżeńskie, dziecko pozamałżeńskie, władza ojcowska, wychowanie, edukacja, dziedziczenie

Keywords: child marriage, child born out of wedlock, paternity, upbringing, education, inheritance

Wiek XVIII, w którym żył i tworzył Jan Jakub Rousseau to okres szczególny z punktu widzenia sytuacji dziecka. W tym bowiem czasie po raz pierwszy z taką siłą do głosu dochodzą pedagodzy i myśliciele, którzy zmieniają sposób podejścia do kwestii funkcjonowania dziecka. Wskazują bowiem na podmiotowość dziecka, potrzebę respektowania jego indywidualności oraz konieczność wyeliminowania surowego karcenia, które w tamtym czasie było synonimem prawidłowych postaw wychowawczych. Po roku 1760 roku pojawiają się zupełnie nowe koncepcje roli dziecka, które w kolejnych stuleciach doprowadzą do umieszczenia jego osoby w ,centrum rodzinnego kosmosu”. Rodzina zaczyna być stopniowo postrzegana jako środowisko ludzi sobie najbliższych, którzy powinni tworzyć więzi oparte na wzajemnej czułości i miłości macierzyńskiej, a nie tylko władzy ojcow- 
skiej (Badinter 1998: 39). W tym okresie ugruntowuje się również przekonanie o całkowitej odrębności dzieciństwa od innych okresów życia człowieka (Ariès 1995: 185-194). Wspomniane koncepcje i poglądy nie wpływają jednak w dostatecznym stopniu na zmianę sytuacji prawnej dzieci, choć w sensie symbolicznym to właśnie pod koniec XVIII wieku, we francuskiej Deklaracji Praw Człowieka i Obywatela z 1789 roku po raz pierwszy w historii użyto terminu ,prawa dziecka”.

Niniejszy artykuł stawia sobie za cel syntetyczne przybliżenie czytelnikowi realiów funkcjonowania dzieci w XVIII wieku na terenie Europy oraz zasygnalizowanie kluczowych aspektów ich egzystowania w rodzinie i społeczeństwie. Autorka posłużyła się terminem „epoka Rousseau” po to, by podkreślić, jak przełomowe dla idei nowej jakości dzieciństwa okazały się poglądy tego francuskiego pedagoga i myśliciela, do którego dzieł powracamy po dzień współczesny, aby na nowo odkrywać ich wartość i uniwersalność.

Sytuacja prawna dziecka od chwili jego urodzenia zdeterminowana była przez fakt przyjścia na świat w legalnie zawartym małżeństwie lub poza nim. Pozycja dzieci małżeńskich i pozamałżeńskich w całej Europie od czasów średniowiecza różniła się bowiem diametralnie. Dzieci urodzone w małżeństwie posiadały pełnię praw w odróżnieniu od dzieci, które pochodziły z tzw. nieprawego łoża. Te ostatnie nie mogły zostać członkami rodziny swojego ojca, a zatem nie były uprawnione do noszenia jego nazwiska. Pozbawiono je również prawa dziedziczenia oraz możliwości korzystania z przywilejów stanowych. Jedyne stosunki pokrewieństwa łączyły je z osobą matki i jej rodziną. Zdarzały się nawet takie regulacje prawne, które zakazywały sprawowania określonych urzędów lub piastowania różnych godności przez dorosłe już dzieci nieślubne; ograniczano w ten sposób ich zdolność do czynności prawnych (Płaza 1997: 249). Jedyną powinnością ojca w stosunku do nieślubnych dzieci mogło być pokrywanie przez krótki czas części wydatków na ich utrzymanie. Niekiedy polskie sądy miejskie nakazywały ojcom, aby dostarczyli określoną ilość produktów spożywczych matkom ich nieślubnych dzieci. W osiemnastowiecznej Francji trybunały apelacyjne również zobowiązywały takich ojców do pokrycia kosztów połogu i wyżywienia noworodków. Orzekane sumy najczęściej oscylowały w granicach od 40 do 150 liwrów i nie starczały nawet na utrzymanie dziecka przez okres 1 roku (Delumeau, Roche 1995: 104). Obowiązek żywienia noworodka, który przyszedł na świat poza zalegalizowanym związkiem nie miał zatem nic wspólnego ze współczesną formą alimentacji. Wiek XVIII przyniósł jednak pewne zwiastuny zmian, które utrwaliły się w systemach prawnych w kolejnych wiekach.

W Polsce w 1768 roku dopuszczono, na podstawie praw kardynalnych, możliwość tzw. legitymacji dziecka pozamałżeńskiego poprzez zawarcie związku małżeńskiego przez jego rodziców w okresie po jego urodzeniu. Znamienne było jednak to, że legitymacja dziecka nie powodowała nabycia przez nie przywilejów właściwych dla stanu szlacheckiego. Za wszelką cenę bowiem broniono dostępu do określonych praw. Przeciwstawiano się kategorycznie możliwości nabywania szlachectwa poprzez małżeństwo dziecka zrodzonego ze związku osoby ze stanu chłopskiego lub mieszczańskiego z przedstawicielem stanu wyższego (Płaza 1997: 249). Zbiór praw sądowych z 1778 roku ustanowił ponadto obowiązek 
alimentacji wobec dzieci urodzonych poza małżeństwem ,póki sobie żywność zarobić nie zdołają" (Borkowska-Bagieńska 1986: 180). Znacząca zmiana na ziemiach polskich w zakresie praw posiadanych przez dzieci nieślubne, nie tylko w zakresie legitymacji, ale również zobowiązania do ich wychowywania i żywienia, nastąpiła dopiero w Kodeksie cywilnym Królestwa Polskiego (Makiłła 2008: 403). Kodeks ten bowiem wprowadził ustawowy obowiązek wychowania i żywienia przez ojców ich nieślubnych dzieci.

Regulacje prawne mające na celu poprawę sytuacji dzieci pozamałżeńskich, jeszcze w XVIII wieku, próbowały wprowadzić inne państwa europejskie. W Austrii zrównano ich prawa z dziećmi małżeńskimi na podstawie Kodeksu Józefińskiego z 1786 roku zaledwie na kilka lat, już bowiem w 1791 roku wycofano się z tej regulacji. Podobna sytuacja wystąpiła we Francji, która pod wpływem zdobyczy Rewolucji wprowadziła równość praw obu kategorii dzieci pod warunkiem dobrowolnego ich uznania przez rodziców. Postanowienia Deklaracji Praw Człowieka i Obywatela wskazywały bowiem na to, że nie powinny istnieć różnice $\mathrm{w}$ statusie prawnym dzieci pochodzących $\mathrm{z}$ oficjalnych i nieoficjalnych związków ich rodziców. Konieczne było jednak uznanie dziecka wyrażone przez jego ojca (Delumeau, Roche 1995: 285). Zanegowanie tej historycznej zmiany w zakresie praw dzieci pozamałżeńskich nastąpiło po kilkunastu latach na podstawie Kodeksu Napoleona z 1804 roku. Należy przy tym mieć na uwadze to, że populacja dzieci pozamałżeńskich nie była marginalna, czego można by oczekiwać, biorąc pod uwagę surowe zasady moralne panujące w ówczesnej Europie. Dane pochodzące z krajów zachodnioeuropejskich wskazują, że w XVIII wieku na wsi rodziło się około $2 \%$ dzieci pozamałżeńskich, zaś w miastach 5\%. Przytoczone dane są bardzo szacunkowe i najprawdopodobniej zaniżone. Głębsza analiza danych demograficznych w dużych miastach europejskich pokazuje rzeczywistą skalę zjawiska. W Warszawie w czasach stanisławowskich przychodziło na świat przeciętnie 15\% dzieci nieślubnych, zaś w takich miastach, jak Paryż czy Praga ich populacja szacowana była nawet na poziomie 35-40\% (Szukalski 2000: 3 i nast.; Kuklo 2009: 386-389). Współcześnie nikt już nie rozpatruje sytuacji prawnej dziecka z punktu widzenia tego, czy przyszło na świat w niezalegalizowanym lub zalegalizowanym związku małżeńskim, a przecież jeszcze stosunkowo nie tak dawno, bo w XVIII i XIX wieku, dziecko nieprawowite nie miało ojca - „tego jedynego ojca rodziny, a zarazem rodzica, wychowawcy, przekaziciela ojcowizny i imienia" (Delumeau, Roche 1995: 281).

Sytuacja dzieci w ówczesnym czasie zdeterminowana była również zakresem władzy rodzicielskiej, która oznaczała de facto władzę ojcowską. Status tej władzy wywodził się ze współistnienia przepisów prawnych pochodzących w istotnej części z prawa kanonicznego i przyjętych przez prawo zwyczajowe z przepisami wywodzącymi się jeszcze z prawa rzymskiego i instytucji pater familias. Istota tej szczególnej relacji pomiędzy ojcem a dzieckiem sprowadzała się do tego, że dziecko pozostawało obiektem jego woli i władzy, istotą, którą zawsze stwarzał pater. Do obowiązków i uprawnień wynikających z władzy ojcowskiej należało najpierw żywić, następnie wychowywać i kształcić po to, by wreszcie zapewnić dorosłem dziecku przyszłość w sensie materialnym. We Francji przed przełomem lat sześćdziesiątych XVIII wieku sądowe źródła langwedockie, odnoszące się 
do środowiska rodzinnego, kładą akcent na wszechwładzę ojca i jego uprawnienia w zakresie wychowania i sukcesji. Ustalenia w tym zakresie można rozciągnąć na wszystkie kraje prawa pisanego w ówczesnej Europie. Wspomniane źródła pomijają aspekt związany z okazywaniem dzieciom uczuć i przywiązują największe znaczenie do roli ojca jako pana domu. Władza ojcowska pozostała niezwykle silna również w zakresie stosunków majątkowych. Ojciec bowiem rozporządzał całym majątkiem rodzinnym, na który składał się zarówno jego majątek osobisty, jak również majątek wniesiony przez jego małżonkę (Makiłła 2008: 196). Ojcu przysługiwało prawo uznania za dziedzica tego potomka, którego sam wybierze. Zazwyczaj był to najstarszy syn. Ojciec nie był zatem zobligowany do traktowania wszystkich dzieci jednakowo a jego władza w określonych sytuacjach rozciągała się także na dorosłych potomków.

Dzieciom urodzonym w XVIII wieku, w szczególności w rodzinach arystokratycznych i szlacheckich, w pierwszych lata życia nie towarzyszyli zazwyczaj ich rodzice. Hołdowano bowiem tradycji wskazującej, że ojciec wkracza w życie dziecka dopiero od pewnego wieku, matka zaś, w szczególności dobrze urodzona, nie powinna ani karmić osobiście, ani zajmować się wychowaniem własnych dzieci, ponieważ przeczyło to zasadom dobrego tonu. Z danych statystycznych drugiej połowy XVIII wieku wynikało, że na dwadzieścia jeden tysięcy dzieci przychodzących na świat w Paryżu tylko jeden tysiąc pozostawał przy matkach i był przez nie karmiony piersią. Kolejnym tysiącem noworodków opiekowały się mamki sprowadzane do domu, zaś przytłaczająca większość dzieci, tj. dziewiętnaście tysięcy, była wysyłana do mamek poza miejsce swego urodzenia (Badinter 1998: 49). Przyczyn tak niezrozumiałej dla współczesnych postawy obojętności matek względem ich nowonarodzonych dzieci początkowo upatrywano w dużej mierze w konieczności nieprzywiązywania się zbytniego do dziecka, które miało bardzo niewielkie szanse na przeżycie. Okazuje się jednak, że najistotniejszym czynnikiem wpływającym na brak więzi między matką a dzieckiem był fakt, że dla ówczesnych społeczeństw miłość macierzyńska nie stanowiła większej wartości ani społecznej, ani moralnej. Nie oczekiwano zatem zbytniego zaangażowania się kobiety w rolę matki (Badinter 1998: 62). Dopiero po 1760 roku sytuacja ta zmieniła się radyklanie, ponieważ miłość macierzyńska uznana została za wielką wartość społeczną, sprzyjającą prawidłowemu rozwojowi jednostki i społeczeństwa. Wykreowany został mit kobiety-matki poświęcającej się w największym stopniu dla dobra swojego dziecka. Sytuacja ta przyniosła rewolucyjną wręcz zmianę w sposobie postrzegania istoty i ważności ról, jakie w życiu dziecka ogrywa ojciec i matka. W kolejnych dziesięcioleciach coraz silniejsza pozycja matki powodowała trwałe odsuwanie w cień pozycji ojca (Badinter 1998: 105). Po okresie niemowlęcym dzieci zazwyczaj pozostawały pod opieką piastunki, bony, a w późniejszym czasie ochmistrzyni. Oddawane były również na wychowanie różnym opiekunom, którzy przywozili je z powrotem do rodzinnego domu po upływie 5-7 lat (Winiarz 1994: 245). Kobiety pochodzące z niższych stanów zdecydowanie częściej samodzielnie opiekowały się małymi dziećmi. Opieka ta trwała mniej więcej do ukończenia przez syna siódmego roku życia, zaś w przypadku córki nieco dłużej (Żołądź-Strzelczyk 2002: 195-196). 
Od momentu zakończenia opieki w pierwszym stadium życia wychowaniem dziecka, w szczególności syna, zaczynał interesować się ojciec, ponieważ to on był najważniejszą, posiadającą niekwestionowany autorytet, osobą w rodzinie. Dziecko winno zawsze okazywać należy mu szacunek, czego symbolem był gest powitania ojca poprzez całowanie jego ręki, obejmowanie jego kolan a nawet padanie do jego nóg (Bystroń 1994: 80). Ówcześni ojcowie, chcąc być w zgodzie z panującymi poglądami na ich rolę, nie okazywali dzieciom czułości i miłości. Byli bowiem zobligowani do trzymania ich na odpowiedni dystans (Żołądź-Strzelczyk 2002: 202). Nieodłącznym atrybutem władzy ojcowskiej było prawo do stosowania wobec swego potomstwa surowych kar cielesnych. Kary te przez długie wieki pozostawały symbolem właściwego wychowania dzieci. Myśliciele i pedagodzy od okresu średniowiecza z dużym zaangażowaniem przedstawiali argumentację przemawiającą za skutecznością bicia dzieci w procesie ich wychowania (Żołądź-Strzelczyk 2002: 218-226). Od epoki renesansu zachodzą stopniowe zmiany w tym zakresie; wyrażają się one w zalecaniu większej ostrożności w wymierzaniu kar cielesnych. Dotychczasowe poglądy w dziedzinie wychowania dzieci, oparte na bezwzględnej dyscyplinie i surowych karach, powoli ustępowały miejsca twierdzeniom, że łagodnością można uzyskać lepsze rezultaty. Nie ulega jednak wątpliwości, że stosowanie wobec dzieci surowych kar cielesnych nadal pozostawało w XVIII wieku najbardziej popularną metodą wpływania na ich zachowanie. Dowodem na to niech będzie wymowny cytat z publikacji jednego z osiemnastowiecznych niemieckich pedagogów - J.G. Krügera: ,,(...) jest rzeczą słuszną i godziwą bić je za wszystkie takie wykroczenia, a także nawet za drobnostki, jeśli popełniły je ze złośliwości (...). Nieposłuszeństwo syna znaczy tyle, co wypowiedzenie wam wojny. On chce wam wyrwać władzę, a wy winniście odpowiedzieć na przemoc przemocą, by potwierdzić wasz autorytet, bez którego nie ma mowy o żadnym wychowaniu. Chłosta zaś, jaką mu wymierzycie, niech nie będzie jedynie czczą igraszką, ale ma go przekonać, że to wy jesteście panem. A bicia macie nie zaprzestać, póki syn nie zrobi tego, czego przedtem ze złośliwości odmawiał" (cyt. za: Miller 1999: 37).

Warto również pamiętać, że w osiemnastowiecznych rodzinach szlacheckich w sposób odmienny traktowano synów i córki. Córki od wczesnego dzieciństwa sposobione były do roli żony. Synowie zaś przygotowywani byli do pełnienia różnych funkcji, które zostały wybrane dla nich przez ojca jako najbardziej odpowiednie. Ten podział w zasadniczy sposób determinował kwestię ich edukacji, która zazwyczaj zaczynała się w okresie, w którym dziecko pozostawało jeszcze w domu rodzinnym. Pierwszymi nauczycielami byli zazwyczaj rodzice, którzy uczyli swoje dzieci czytania i pisania oraz języków obcych takich, jak łacina, francuski czy niemiecki. W przypadku córek nacisk położony był również na naukę śpiewu i muzyki oraz umiejętności praktycznych w zakresie prowadzenia domu. Edukacja domowa synów stanowiła swego rodzaju preludium do dalszego kształcenia w szkołach, natomiast w przypadku córek zazwyczaj kończyła proces zdobywania wiedzy (Żołądź-Strzelczyk 2002: 228). Zdarzały się jednak przypadki dalszego kształcenia dziewcząt w klasztorach żeńskich, na dworach magnackich bądź powstających od XVII wieku pensjach prywatnych, prowadzonych głównie przez cudzoziemców w większych 
miastach. Nie ulega jednak wątpliwości, że edukacja kobiet pozostawała na niezadowalającym poziomie. W drugiej połowie XVIII wieku pojawiały się jednak poglądy wskazujące na konieczność zmiany w zakresie podejścia do kształcenia dziewcząt, zwłaszcza pochodzących z rodzin szlacheckich. Działająca w tamtym czasie Komisja Edukacji Narodowej, która przystąpiła w Polsce do reformy wychowania narodowego, postulowała, aby kobiety „równo z mężczyznami od młodości lat sposobione były”. Wskazywano na konieczność ich kształcenia w poczuciu odpowiedzialności za losy kraju. Główny nacisk w edukacji dziewcząt miał zostać położony na wybitną znajomość języka ojczystego i historii narodowej oraz języków obcych i arytmetyki. Ostatecznie okazało się, że konserwatywna społeczność szlachecka nie poparła tych rewolucyjnych zmian w podejściu do kształcenia przedstawicielek płci żeńskiej. Pensje dla panien nie dostosowały się do wyżej wskazanych zaleceń, dając nadal społeczeństwu polskiemu tylko ,żony modne” i ,pustomyślskie" (Kurdybacha 1965: 691-693).

Należy przy tym zauważyć, że kwestia edukacji całego społeczeństwa zaczęła być mocno akcentowana pod koniec XVIII wieku w całej Europie. Szczególna debata na ten temat odbywała się we Francji pod wpływem myśli rewolucyjnej. W 1792 roku opracowano plany przewidujące „ustanowienie prawdziwie narodowego systemu wychowania, prawdziwie republikańskiego, jednakowo i rzeczywiście dostępnego dla wszystkich”. Dążono do tego, aby państwo z własnych środków zapewniło edukację wszystkim chłopcom w wieku od 5 do 12 lat oraz wszystkim dziewczynkom w wieku 5 do 11 lat. Zanegowana została wartość kształcenia domowego. Państwo francuskie nie było oczywiście w stanie z przyczyn finansowych zrealizować tak ambitnego projektu kształcenia dzieci. Ciekawe jest jednak to, że próby wprowadzenia powszechnego obowiązku szkolnego zostały potraktowane w znacznej mierze jako zamach na władzę ojcowską. Uznano bowiem, że w takiej sytuacji dziecko stanie się własnością republiki, a nie jak do tej pory własnością ojca (Delumeau, Roche 1995: 277-278).

Nie sposób nie wspomnieć o tym, jak istotną kwestią w życiu dorastającego dziecka pozostawało zawarcie przez niego w przyszłości związku małżeńskiego. Możliwość podejmowania decyzji w tym względzie posiadali wyłącznie rodzice. Przez cały XVIII wiek, zwłaszcza w rodzinach wyższych stanów, wciąż aranżowano związki małżeńskie a do ich zawarcia wymagana była zgoda rodziców. Małżeństwo dziecka miało na celu umacnianie pozycji rodziny, dlatego tak istotny pozostawał wybór odpowiedniego kandydata lub kandydatki. Dopiero w ostatnich latach XVIII wieku dorosłe dzieci zyskały większy wpływ na wybór swojego współmałżonka (Wróbel-Lipowa 2002: 109). Niemniej jednak zawarcie małżeństwa wbrew woli rodziców traktowane było nadal jako wyraz wielkiej niewdzięczności wobec nich i zazwyczaj miało poważne konsekwencje, wiązało się bowiem z wydziedziczeniem. Małżeństwo oznaczało uwolnienie się spod władzy ojca. Syn stawał się dorosłym, córka zaś spod „kurateli ojcowskiej przechodziła pod opiekę męża” (Wróbel-Lipowa 2002: 105). Uprawnienia ojca do decydowania o losach dziecka wygasały zatem w momencie zawarcia przez nie związku małżeńskiego, choć nie była to jedyna przyczyna takiego stanu rzeczy. Władza rodzicielska wygasała również w momencie 
śmierci ojca, uzyskania pełnoletności, która zazwyczaj kształtowała się w ówczesnym czasie na poziomie 25 lat dla mężczyzn i 20-24 lat dla kobiet, wstąpienia do zakonu w przypadku córek oraz powołania do służby publicznej lub uzyskania przed osiągnięciem pełnoletności własnego majątku w przypadku synów (Szafrański 2007: 232). Istotny pozostaje fakt, że córki, wychodząc za mąż, otrzymywały zazwyczaj posag, synowie zaś zyskiwali prawo do ubiegania się o wydzielenie im tzw. dóbr macierzystych, tj. składników z majątku nieżyjącej matki, na który składał się jej posag i wiano (Uruszczak 2010: 303). Inną sposobnością do pozyskania składników z rodzinnego majątku było dziedziczenie po zmarłym ojcu, przy którym uwzględniano głównie interes synów. Dziedziczenie w ich przypadku odbywało się w równych częściach i obejmowało prawo do objęcia nieruchomości. Takich uprawnień nie posiadały córki. Te z nich, które otrzymały posag musiały zrzec się prawa do dziedziczenia całości majątku rodzinnego pochodzącego zarówno od ojca, jaki i od matki. Wyjątek stanowiła sytuacja, gdy córka nie otrzymała stosownego uposażenia na okoliczność zawarcia związku małżeńskiego. W takich okolicznościach jej prawo do dziedziczenia uprawniało ją do ubiegania się o wyznaczenie przez braci „zaległego" posagu, a w przypadku niewyjścia jeszcze za mąż - o łożenie na jej utrzymanie. Polepszenie pozycji spadkowej córek następowało stopniowo od połowy XVII wieku, kiedy to ustanowiona została instytucja tzw. czwarcizny polegająca na tym, że czwarta część całej masy spadkowej przypadała zawsze córkom (Uruszczak 2010: 305). Wracając jednak do kwestii zawarcia związku małżeńskiego wbrew woli ojca, podkreślić należy, że nie było to jedyne zachowanie, które mogło rodzić negatywne konsekwencje prawne dla dorosłych dzieci. Ojciec w ramach posiadanej władzy mógł bowiem zakazać dzieciom pełnoletnim podejmowania różnego rodzaju hańbiących przedsięwzięć, do których zaliczano m.in. ciężką zniewagę, srogie obchodzenie się, zamach na mienie, niewykonanie zobowiązań ciążących na spadku dziedziczonym. Przedmiotowe zachowania traktowane były jak przypadki rażącej niewdzięczności dziecka w stosunku do rodziców. Mogły podpadać pod kategorię tzw. złego prowadzenia się, które narażało na szwank honor i spokój rodziny, dlatego też dawały rodzicom uprawnienie do żądania dla syna lub córki kary uwięzienia lub deportacji. Rodzice nie odpowiadali ponadto za występki i długi swoich dzieci, które zostały popełnione bez ich wiedzy (Szafrański 2007: 231-233). We Francji w 1763 roku, dnia 15 lipca wydany został akt dotyczący młodych ludzi, ,którzy popadli w życie mogące zagrozić honorowi i spokojności ich bliskich". Na jego mocy rodzice mieli prawo występowania do Departamentu Wojny i Marynarki w celu deportacji swoich dzieci na wyspę La Desirada, gdzie poddawano je surowemu systemowi nadzoru w celu doprowadzenia do poprawy ich zachowania w przyszłości (Badinter 1998: 34).

Wskazane wyżej przykłady regulacji prawnych pokazują dobitnie jak istotne dla ówczesnych zhierarchizowanych społeczeństw było podtrzymanie idei bezwzględnego posłuszeństwa dzieci, nawet dorosłych, względem władzy ojcowskiej. Rodzice również ponosili odpowiedzialność za nadużycia w stosunku do swoich dzieci. Wspomniany już Kodeks Józefiński z 1786 roku zwracał uwagę na konieczność podlegania władzy ojca i jego woli, o ile nie naruszała ona praw powszechnie obowiązujących i przyjętych zasad 
obyczajowych. W przedmiotowym kodeksie ustanowiono przepisy, które nie tylko umożliwiały wystąpienie do sądu przeciwko rodzicom sprzeciwiającym się wyżej wskazanej zasadzie, ale stwarzały również możliwość pozbawienia ojca władzy rodzicielskiej w sytuacji, gdy zaniedbywał on swoje podstawowe obowiązki względem dziecka dotyczące konieczności jego wyżywienia i wychowania. Na ziemiach polskich osiemnastowieczne regulacje prawne nie szły tak daleko w zakresie możliwości zakwestionowania władzy ojcowskiej. Zbiór praw sądowych z 1778 roku wprowadzał przepisy zakazujące powoływania dzieci na świadków przeciwko ojcu, uznawał również konieczność wydziedziczenia ich w sytuacji skierowania przeciwko rodzicom oskarżeń „o przestępstwo, za które kara śmierci jest postanowiona” (Borkowska-Bagieńska 1986: 181).

Do najpoważniejszych nadużyć wobec dzieci ze strony rodziców należało porzucenie oraz dzieciobójstwo. Przyczyną popełniania tych czynów była zazwyczaj trudna sytuacja ekonomiczna oraz chęć ukrycia faktu przyjścia na świat nieślubnego dziecka. W XVI wieku rodzice, którzy dopuścili się porzucenia dziecka karani byli śmiercią. Z czasem jednak, w zależności od stopnia szkodliwości czynu, zaczęto orzekać różne kary, od chłosty po wygnanie. Na początku XVIII wieku obawa przed mnożeniem się przypadków aborcji i dzieciobójstwa sprawiła, że w sytuacji porzucenia dziecka kara cielesna została zamieniona na karę pieniężną. Wprowadzono również regulacje zezwalające na opuszczenie dzieci zgodnie z prawem, to znaczy poprzez pozostawienie ich w szpitalach miejskich, które zaczęto powoływać do życia w drugiej połowie XVII wieku. Zamiast porzucać zatem dzieci w lesie, co stanowiło oczywiście czyn karalny, ojcowie zaczęli oddawać je do szpitali, co tak naprawdę stanowiło jedynie ,gest iluzorycznego człowieczeństwa”, ponieważ tam dzieci i tak zazwyczaj umierały (Delumeau, Roche 1995: 105). Wiek XVIII został w późniejszym okresie nazwany „wiekiem podrzutków” z powodu wyraźnego wzrostu liczby dzieci, które pozostawiane były nie tylko w szpitalach, ale w powstających w tamtym czasie placówkach wyspecjalizowanych w opiece nad nimi (Kuklo 2009: 393).

Najpoważniejszym przestępstwem przeciwko dziecku było bez wątpienia dzieciobójstwo, które karane było kwalifikowaną formą kary śmierci poprzez zakopanie żywcem lub wbicie na pal. W pierwszej połowie XVIII wieku na terenie Saksonii popularna była również kara śmierci polegająca na zawiązaniu w worku i utopieniu, zaś na terenie Danii dzieciobójczynie zazwyczaj publicznie wieszano. Odpowiedzialności karnej podlegały nie tylko kobiety dokonujące zabójstwa dziecka, które urodziło się żywe, ale również te, które w toku postępowania wskazywały, że urodziły one martwe potomstwo. W drugiej połowie XVIII wieku na terenie całej Europy coraz częściej postulowano konieczność złagodzenia odpowiedzialności karnej za to przestępstwo. W 1765 roku na terenie Prus wydany został edykt Fryderyka Wielkiego, który kwalifikowaną formę kary śmierci za dzieciobójstwo zamienił na zwykłą karę śmierci poprzez ścięcie mieczem. Jeszcze dalej idące zmiany zaobserwować możemy w ustawodawstwie toskańskim z 1786 roku, w którym zniesiono całkowicie karę śmierci i za przedmiotowy czyn wprowadzono karę dożywotnich robót przymusowych. Docelowo europejskie kodeksy karne uregulowały dzieciobójstwo w odrębnych przepisach, czyniąc z niego tzw. przestępstwo uprzywilejowane, zagrożone niż- 
szą karą pozbawiania wolności niż w przypadku zwykłego zabójstwa. Tak istotna zmiana w sposobie kwalifikacji odpowiedzialności karnej za ten czyn ugruntowała się ostatecznie w XX wieku, choć na niektórych obszarach, jak w przypadku Bawarii, przedmiotowe rozwiązania wprowadzono już w 1813 roku (Księżopolska-Breś 2010: 12-15).

Na uwagę zasługuje fakt, że w drugiej połowie XVIII wieku widać zalążki zamian w zakresie równouprawnienia rodziców. Na ziemiach polskich niebagatelną zmianę w zakresie postrzegania władzy rodzicielskiej wprowadził przywoływany już Zbiór praw sądowych, który został przygotowany i przedłożony sejmowi przez Andrzeja Zamojskiego w 1778 roku. Zmiana ta polegała na tym, że w miejsce władzy samego ojca wprowadzono „rządy ojca i matki” (Płaza 1997: 249). Została ona utrwalona w późniejszych regulacjach prawnych, między innymi w ustawodawstwie cywilistycznym Królestwa Polskiego, w którym władzę rodzicielską przyznano wprost obojgu rodzicom, czyniąc ojca silniejszym jedynie w sytuacji różnicy zdań (Makiłła 2008: 404). Na definitywną zmianę w tym zakresie trzeba było poczekać jednak aż do drugiej połowy XX wieku, kiedy to w większości systemów prawnych państw europejskich nastąpiło całkowite zrównanie w prawach ojców i matki.

Pod koniec XVIII wieku pojawiły się symptomy zmierzania do pewnego ograniczenia dotychczasowej władzy ojcowskiej. W najbardziej jaskrawy sposób odzwierciedla to prawo rewolucyjnej Francji. Na podstawie ustawy z dnia 24 sierpnia 1790 roku ustanowione zostały trybunały rodzinne, których zadaniem było rozstrzyganie w przedmiocie dotychczasowego prawa ojca do uwięzienia własnego syna. Ograniczona została zatem absolutna arbitralność ojca w prawie karcenia. Ponadto, w ustawie potwierdzającej akty stanu cywilnego z 20 sierpnia 1792 roku, znalazły się przepisy, które zapewniały synom i córkom pełną swobodę w zawieraniu małżeństw oraz znosiły „karę wydziedziczenia nakładaną na dzieci, które zawierają związki małżeńskie bez zgody ich ojców lub matek". Czas pełnoletności został wówczas określony na 21 lat, co oznaczało, że po ukończeniu tego wieku dziecko nie będzie już musiało prosić o zgodę rodziców na ożenek lub zamążpójście. Jeszcze dalej idącą propozycją zmian w zakresie władzy ojcowskiej były artykuły ustawy unifikującej prawodawstwo francuskie z dnia 28 sierpnia 1792 roku, które wskazywały, że władza ta będzie dotyczyć jedynie dzieci małoletnich, nie będzie się natomiast rozciągać na osoby pełnoletnie (Delumeau, Roche 1995: 289-290). Należy zwrócić również uwagę na treść francuskiego dekretu z 8 kwietnia 1791 roku, który znosił wszelkie nierówności pomiędzy dziećmi w prawie dziedziczenia, „,czy to z tytułu różnicy wieku (dziecka starszego lub młodszego), czy odmienności płci lub wykluczeń zwyczajowych”. Ustawodawstwo rewolucyjne odebrało zatem ojcu prawo do traktowania w uprzywilejowany sposób tylko jednego lub wybranych przez siebie dzieci. Od tego momentu miała obowiązywać zasada pełnej równości wszystkich dzieci w byciu spadkobiercami. Istniało jednak ryzyko, że ojcowie zechcą skorzystać z wciąż obowiązującego prawa do samodzielnego rozporządzania swoim mieniem pośmiertnym na podstawie testamentów, dlatego też dekretem z 7 marca 1793 roku prawo to zostało zniesione (Delumeau, Roche 1995: 292-293). Opisane zdobycze prawne Rewolucji Francuskiej zostały uznane na początku 
XIX wieku za niszczenie władzy ojcowskiej. Jak pisał Balzak: „Rewolucja ścięła głowy wszystkim ojcom rodziny. Odtąd są oni już tylko zwykłymi jednostkami” (Delumeau, Roche 1995: 13). Dawny porządek przywrócony został jednak na podstawie wspomnianego już Kodeksu Napoleona, który wskrzeszał pierwotną władzę ojcowską.

Podsumowując powyższe rozważania, nie trudno dojść do przekonania, że w epoce Rousseau sytuacja prawna dziecka wciąż zakorzeniona była w wielowiekowej tradycji silnej władzy ojcowskiej. Obejmowała ona jego prawa i obowiązki w zakresie opieki, wychowania i wykształcenia dziecka, zarządzania jego majątkiem i wyrażania zgody za zawarcie związku małżeńskiego. W XVIII wieku ojciec bez wątpienia miał wciąż niekwestionowaną pozycję głowy rodziny. Uprawnienia ojca nie były jednak nieograniczone. Nie wolno mu było czynić niczego, co miałoby na celu tylko i wyłącznie jego osobisty interes. Nie miał on tych samych praw, które patria potestas zapewniała rzymskiemu ojcu rodziny. Nie mógł porzucić, czy sprzedać swoich dzieci, a tym bardziej decydować o ich życiu lub śmierci (Żołądź-Strzelczyk 2002: 22). Druga połowa XVIII wieku wyraźnie zapowiada przyszłe zmiany prawne związane z osłabianiem władzy ojca i wzmacnianiem pozycji dziecka, niezależnie od tego czy przyszło ono na świat w zalegalizowanym związku małżeńskim, czy poza nim. Rozpoczął się, trwający przez kolejne dwa stulecia intensywny proces upodmiotowienia jego osoby.

\section{Literatura}

Ariès P. (2010), Historia dzieciństwa. Dziecko i rodzina w czasach ancien régime'u. Warszawa, Wyd. Aletheia.

Badinter E. (1998), Historia miłości macierzyńskiej. Warszawa, Oficyna Wydawnicza Volumen.

Borkowska-Bagieńska E. (1986), Zbiór praw sądowych Andrzeja Zamoyskiego. Poznań, Wyd. Naukowe Uniwersytetu Adama Mickiewicza w Poznaniu.

Bystroń J.S. (1994), Dzieje obyczajów w dawnej Polsce. Wiek XVI-XVIII. Warszawa, PIW.

Delumeau J., Roche D. (1995) (red.), Historia ojców i ojcostwa. Warszawa, Wyd. Szkolne i Pedagogiczne.

Księżopolska-Breś A. (2010), Odpowiedzialność karna za dzieciobójstwo w prawie polskim. Warszawa, Oficyna.

Kuklo C. (2009), Demografia Rzeczypospolitej Przedrozbiorowej. Warszawa, Wyd. DiG.

Kurdybacha Ł. (1965) (red.), Historia wychowania. Warszawa, PWN.

Makiłła D. (2008), Historia prawa w Polsce. Warszawa, PWN.

Miller A. (1999), Zniewolone dzieciństwo. Ukryte źródła tyranii. Poznań, Media Rodzina.

Płaza S. (1997), Historia prawa w Polsce na tle porównawczym, cz. I: X-XVIII w. Kraków, Księgarnia Akademicka Wyd. Naukowe.

Szukalski P. (2000), Urodzenia pozamatżeńskie w Europie Zachodniej. Łódź, Wydawnictwo Uniwersytetu Łódzkiego.

Winiarz A (1994), Polskie rodziny arystokratyczne i szlacheckie w XVIII i XIX wieku jako środowisko wychowawcze. W: J. Jundziłł (red.), Wychowanie w rodzinie od starożytności po wiek XX. Bydgoszcz, Wydaw. Uczelniane WSP. 
Wróbel-Lipowa K. (2002), Relacje dzieci-rodzice w polskiej rodzinie ziemiańskiej w XVIII wieku.

W: K. Jakubiak, W. Jamrożek (red.), Dziecko w rodzinie i społeczeństwie. Dzieje nowożytne. Bydgoszcz, Wyd. Uczelniane Akademii Bydgoskiej.

Uruszczak W. (2010), Historia państwa i prawa polskiego. Tom I (966-1795). Warszawa, Oficyna

Wolters Kluwer.

Szafrański W. (2007), Kodeks Stanisława Augusta. Poznań, Wydawnictwo Poznański.

Żołądź-Strzelczyk D. (2002), Dziecko w dawnej Polsce. Poznań, Wydawnictwo Poznańskie. 